Competition Rules in the Euromed Countries with a special emphasis on network industries

Professor Damien Geradin

BAT. B31 Faculté de Droit

Boulevard du Rectorat, 7

4000 Liege - Belgium

D.geradin@ulg.ac.be

Nicolas Petit

BAT. B31 Faculté de Droit

Boulevard du Rectorat, 7

4000 Liege - Belgium

Nicolas.Petit@ulg.ac.be

http://www.ulg.ac.be/ieje 


\title{
Competition Rules in the Euromed Countries with a special emphasis on network industries
}

\author{
Damien Geradin* and Nicolas Petit**
}

Paper presented at the World Bank ABCDE Conference, Paris, 15-16 May 2003

\section{Introduction}

It is generally accepted that competition between firms is the best way to provide for an optimal allocation of resources, impose pressure on costs and stimulate innovation and consumer satisfaction (Gellhorn and Kovacic 1994). It is, however, possible that firms try to eliminate competition by adopting anti-competitive practices. For this reason, the adoption and implementation of competition rules is necessary. By preventing anti-competitive practices, the application of these rules contributes to economic efficiency, as well as to welfare maximisation. Competition rules may also pursue other objectives. This is, for instance, the case in the European Community (EC) where one of the major objectives of competition policy is to contribute to the creation of a single market (Elhermann 1992).

While competition law regimes have for a long period of time only been present in industrialised countries, a large number of emerging economies have now adopted domestic competition rules. This can be explained by a number of factors. First, some emerging economies have enacted competition rules in the framework of free trade agreements (e.g. NAFTA or Mercosur). Second, institutional donors, such as the World Bank or regional development banks, generally encourage emerging economies to adopt competition law regimes and provide assistance to these countries in order to help them establish such regimes. Finally, a number of emerging economies realised that the implementation of fundamental economic reforms, such as the liberalisation of State monopolies, had to be accompanied by the adoption of rules preventing anti-competitive practices (Jenny 2001).

The development of competition policies in countries of Central and Eastern Europe (CEECs), in Latin America and in Asia has received considerable academic attention (Cuningham and LaRocca 1996). In contrast, the development of competition law regimes in Northern Africa and in the Middle East has not received comparable

\footnotetext{
* Professor of Law and Director, Institute for European Legal Studies, University of Liège. Professor at the College of Europe and Research Director of the Global Competition Law Centre (GCLC), Bruges.

** Research fellow and doctoral candidate, Institute for European Legal Studies, University of Liège. The present study has benefited from financial support from the Interuniversity Poles of Attraction Program P5/32 initiated by the Belgian State, Prime Minister's Office - Federal Office for Scientific, Technical and Cultural Affairs.
} 
interest. The main objective of this paper is thus to fill this gap in the literature by examining the state of adoption and implementation of competition rules in the 12 Mediterranean countries (hereafter, the "Euromed countries") engaged in association agreements with the EC in the framework of the Barcelona Declaration of November 1995. Indeed, these agreements not only contain trade related provisions, but also include competition rules. Moreover, independently of the association agreements, some Euromed countries have decided to adopt domestic competition law regimes.

A related objective of this paper is to discuss why adoption of competition law regimes is important in emerging economies, in particular as a necessary component of the market-opening reforms undertaken by a number of Euromed countries in the area of network industries (telecommunications, postal services, energy, and transport). Competition rules have played a very important role in the liberalisation process in the EC (Geradin 1999). There is every reason to believe that competition rules could play a similarly important role in the Euromed countries that have engaged in the liberalisation of their network industries.

Following this introduction, Part II analyses two issues. The first is the relationship between competition and trade, which are often seen as complementary policies. This issue is of central importance as the association agreements concluded by the EC and the Euromed countries are primarily about promoting free trade, and the insertion of competition rules in these agreements participates to this objective. The second is whether the adoption of competition law regimes is desirable in emerging economies. Part III discusses the importance of adopting a competition regime in support of market-opening reforms in the area of network industries. Part IV analyses the competition rules inserted in the association agreements concluded between the EC and its Euromed partners. Part V reviews the domestic competition regimes that have been adopted by the Euromed countries. Finally, Part VI contains a brief conclusion.

\section{Competition, Trade and Emerging Economies}

In this Part, we will successively review the relationship between trade and competition policy (A), as well as the relationship between competition and economic development (B).

\section{A. Competition and Trade}

For almost half a century, the interface between trade and competition policies has received considerable attention from policy-makers, practitioners, and academics (Wood 1992). The point of connection between these policies is that it is widely believed that free trade among nations does not only require the removal of public barriers to trade (e.g., quotas, custom duties, etc.), but also a series of obstacles originating in private restraints, such as abuse of dominance, import cartels, and vertical restraints (Fox 1997). Competition policy would thus be a necessary complement to trade policy.

The importance of competition policy as a tool to promote market integration has long been understood in the EC (Ehlermann 1992). Promoting the creation of a single market has always been seen as one of the major objectives of EC competition law 
(Bellamy and Child 2001). Competition rules have been applied, for instance, to prevent vertical restrictions, which would contribute to dividing markets along national lines. The European Commission is also taking an increasingly tough stance against cartels involving companies from different Member States as such cartels generally have a market partitioning effect (Monti 2002).

More recently, competition rules have been inserted in a series of regional or bilateral trade agreements concluded by the EC, such as the European Economic Area (EEA) or the association agreements concluded by the EC with a variety of third countries. A similar approach can also be found in agreements concluded in other parts of the world. For instance, the Protocol for the Defence of Competition in Mercosur contains an ambitious agenda whereby member countries are called to harmonize their domestic competition laws and institutions are created to prevent anti-competitive behaviours that affect trade among the member countries (Tavares de Araujo and Tineo 1998).

The relationship between trade and competition policies is also a major issue at the WTO level (Tarullo 2000). Since the beginning of the 1990s, the EC has pressed its trading partners for the adoption of a competition law framework in the context of the WTO (Fox 1997). In 1996, the WTO Ministerial Meeting held in Singapore created a Working Group on the Interaction between Trade and Competition Policy. The mission of this Working Group was to "study issues raised by Members relating to the interaction between trade and competition policy, including anti-competitive practices, in order to identify any areas that may merit further consideration in the WTO framework". This Working Group has produced several reports, which will provide support to further WTO initiatives in the competition field. In this regard, the recent Doha Ministerial Declaration represented another major step as it provided that negotiations over competition will take place after the next WTO Ministerial Meeting, probably in 2003, based on modalities to be decided at the time. It is, of course, too early at this stage to predict whether these negotiations will lead to the adoption of a WTO competition law framework.

\section{B. Competition and Emerging Economies}

These last two decades have seen a large number of emerging economies adopting competition law regimes. The development of such regimes in emerging economies remains, however, a controversial matter.

On the one hand, many authors argue that adoption of competition law regimes will be beneficial for emerging economies (Anderson and Holmes 2002). First, it is argued that the existence of a competition policy was a factor contributing to economic development. Michael Porter, for instance, identifies a clear connection "between domestic rivalry and the creation and persistence of competitive advantage in an industry" (Porter 1990). A strong competition policy would thus be essential to the upgrading of an economy. Second, it is argued that developing countries are particularly vulnerable to international cartels involving firms based in the developed world (Levenstein and Suslow 2001). The vulnerability of such countries would be in great part due to their inability to identify and prosecute such practices effectively. It is thus claimed by some that the best way for these countries to protect themselves against such practices is to adopt effective competition law regimes and institutions 
(Anderson and Holmes 2002). Third, some authors argue that one of the benefits of creating effective competition law institutions in emerging economies is that such institutions could engage in competition advocacy (Kovacic 1997). For instance, they could promote competition by making the case for removal of regulatory or other restrictions so as to allow entry in certain sectors of the economy, which have been traditionally sheltered from competition. On the other hand, arguments are sometimes raised that emerging economies do not need a competition law framework. These arguments, however, fail to convince.

First, it is sometimes argued that free trade would be by itself sufficient to protect the competitive process. It is certainly true that opening borders contributes to discipline firms, as imported products will compete with the local products. This argument, however, does not take into account the fact that there are non-tradable products and services, the providers of which will not be disciplined by import competition. Moreover, while the removal of State-induced barriers to trade, such as tariffs or quotas, allows entry of foreign competitors, such an entry can be made difficult or sometimes even impossible by anti-competitive measures. As we have seen above, restrictive agreements, such as vertical restraints and cross-border cartels, may have the effect of isolating national markets.

Second, it is also sometimes argued that adoption of competition rules may be counterproductive in small economies. Application of such rules might, for instance, prevent some mergers necessary to help domestic players to gain the size necessary to be competitive on regional or international markets. However, this does not mean that no competition law should be adopted in such countries. It rather means that small economies need a competition policy that takes into account the specific market circumstances of these countries. For instance, Gal argues that "small economies need a specially tailored competition policy, because they face different welfare maximization issues than large ones" (Gal 2001). More specifically, she claims that, given the importance of allowing producers in these countries to realize economies of scale, competition policy should exclusively focus on the promotion of economic efficiency, which should be given primacy over other goals sometimes promoted by competition regimes, such as the dispersion of economic power and the protection of small businesses.

Finally, some observers make the argument that competition policy would be a luxury for rich countries and that developing and transition economies have other, more pressing priorities. It is true that adoption and implementation of a competition policy might not be the most pressing reform for a country that has engaged on the path of a market economy. It does not mean, however, that such a policy would not be useful. As will be seen in the next Part, a sound competition policy generally helps transition economies to ensure that the benefits brought about by the "first generation" of reforms, such as trade liberalization or market-opening reforms, are not being impaired by anti-competitive practices. In this regard, one of the great values of competition policy is that it has an economy-wide effect. It will thus help consolidate reforms not only in one sector, but in all sectors which have been opened to competition.

\section{Competition Policy and Network Industries}


One sector in which the absence of an effective competition law regime may create considerable difficulties relates to "network industries". The concept of network industries generally refers to a variety of industries that operate on the basis of a network. These include telecommunications networks and services, postal services, energy and gas, rail and air transport. In all parts of the world, these industries were traditionally dominated by public or private monopolies. In recent years, however, many nations, including some Euromed countries, engaged in major regulatory reforms seeking to promote competition in network industries markets (Newbery 2000). There are a number of reasons why several Euromed countries decided to liberalise network industries.

First, in most Euromed countries, the performance of monopoly undertakings is generally not satisfactory. In the telecommunications sector, teledensity and other relevant indicators remain low in most Euromed countries. For example, in 2000, only $5,03 \%$ of the Moroccan population had access to a fixed telephone line (Goldstein 2002). In addition, a large section of the population remains unserved as waiting lists for telephone connections are generally long. Once again, in 2000, in Morocco, $1,275,000$ persons or businesses were on a waiting list for a fixed telephone line.

Second, the globalisation of the economy forces companies to be competitive. This is especially true in export-oriented economies like most Euromed countries. In order to remain competitive companies try to lower costs by seeking cheaper inputs. This leads industry associations to call for market-opening reforms in network industries. They expect that competition in these industries will lower prices, especially for industrial users.

Third, liberalisation of network industries may also be triggered by external pressures. A number of Euromed countries, including Cyprus, Egypt, Israel, Jordan, Malta, Tunisia and Turkey, are members of the WTO and, during the last round of multilateral negotiations, committed themselves to progressively open some of their network industries markets to competition. Institutional donors also put pressure on Euromed countries to liberalise these markets as part of a package of structural reforms.

Finally, several Euromed countries have come to realize that regulatory reforms in network industries undertaken in industrialized countries, but also in some emerging economies, could provide many benefits. The liberalization of the telecommunications sector in Chile, for instance, is generally cited as an example of a successful opening of the market (Kerf and Geradin 2000). Prices went down, quality of service improved, and access to telecommunications services largely increased. Inspired by these experiences, technocrats in some Euromed countries convinced their governments to engage into regulatory reforms in network industries (Goldstein 2002).

While there is a solid case for liberalisation, market-opening reforms have often met considerable resistance in Euromed countries. First, incumbents have generally opposed the removal of their monopoly rights. Given their proximity to the government, incumbents have a powerful voice and their arguments against liberalisation will often be taken into consideration. Second, liberalisation is a 
complex and time-consuming process and, given the delicate economic situation in which Euromed countries are found, other, more pressing, reforms may be on the agenda of their governments. Third, Euromed governments engaged in privatisation of some of their incumbents might be tempted to delay the liberalisation process in order to obtain a higher sum of money from foreign investors. Fourth, frequent changes of leadership in government and lack of vision for the future of network industries may prove considerable obstacles for ambitious market-opening reforms in these industries.

In spite of these obstacles, a number of Euromed countries have engaged in the liberalisation of network industries. This is a complex process in which a great deal of public intervention is required. Network industries hold certain features that make the creation of competitive markets difficult (e.g., the natural monopoly feature of the network that is owned by the incumbent) (Geradin 1999). The analysis that follows shows that the adoption and implementation of competition rules is an essential component of successful market-opening reforms in network industries. Absence of competition rules could make the arrival of competition difficult and, thus, deprive undertakings and consumers of much of the benefits liberalisation could produce.

It is generally admitted that creating competition in these industries relies on three main pillars. First, governments need to remove the exclusive rights granted to incumbent operators. In most nations, the complete removal of such rights takes several years. Liberalization also tends to progress faster in some industries than in others. Generally, the first sector to be opened to competition is telecommunications, while market-opening reforms in other sectors generally follow several years later. These features can also be found in Euromed countries. First, those Euromed countries that have engaged in liberalization measures have generally done so progressively. For instance, in Egypt, all value-added services (Internet, Mobile, Audio-Text, Data) have been liberalized, while the incumbent will retain its monopoly on fixed telephony lines until December 2005 (Goldstein 2002). Moreover, most liberalization efforts have generally taken place in the telecommunications sector. At present, ten Euromed countries (Algeria, Cyprus, Egypt, Israel, Jordan, Lebanon, Malta, Morocco, Tunisia and Turkey) are engaged in some form of telecommunications liberalization. By contrast, few market-opening initiatives have so far been taken in other network industries (Andress 2002 and Müller Jentsch 2002).

Second, in all industries partially or totally opened to competition, governments need to adopt a sector-specific regulatory framework, as well as to create specialised regulatory institutions (Kerf and Geradin 1999). One central objective of such a regulatory framework is to prevent incumbents from abusing their market power. During a number of years following liberalisation, incumbent operators will usually retain a high market share, as well as the control of essential infrastructures. It will thus be generally easy for them to leverage their market power in order to prevent entry of new competitors, for instance by cross-subsidising competitive services with services that remain under monopoly control or by refusing access to essential infrastructures. Rules thus need to be adopted to prevent such behaviour, as well as to create a level playing field between incumbents and new entrants. The Euromed countries that have engaged in market-opening reforms have generally adopted sectorspecific regulatory frameworks. In the telecommunications sectors, for instance, several Euromed countries have enacted legislation aiming to regulate the provision of 
telecommunications services. For instance, in Algeria, Law N²000-03 regulates a range of issues such as licensing, the allocation of radio-electric spectrum, as well as the regime of penalties applicable to operators that violate the law. In addition, all the Euromed countries that have engaged in telecommunications liberalisation have created regulatory institutions.

Finally, market-opening reforms in network industries require that competition rules be applied to such sectors (Larouche 2000). Even in industries where sector-specific rules have been adopted, competition rules remain essential for a number of reasons. First, competition rules are needed - and indeed best suited - to deal with a range of economic regulation issues that are not addressed by the sector-specific rules described above. Mergers are a key example. Market-opening reforms in network industries trigger a number of mergers that may lead in turn to excessive market consolidation. Merger control procedures thus need to be established and used to prevent those mergers that would restrain competition. Second, competition rules may have a residual role and fill gaps that might exist in sector-specific regulatory regimes. For instance, when interconnection rules are insufficiently clear, competition rules preventing abuses of a dominant position can be relied upon by new entrants to obtain access to essential infrastructures. Finally, competition rules may be used to impose structural remedies when appropriate sector-specific rules appear to be lacking on this topic. For instance, the break-up of AT\&T in the early 1980s, which was imposed more than a decade before the liberalisation of all segments of the US telecommunications market, constitutes a well-known example of reliance on competition rules to implement structural remedies in the US telecommunications market (Brennan 1987).

For these reasons, the failure to establish effective competition law regimes may be an obstacle to regulatory reforms in network industries in Euromed countries. In the absence of such regimes, there is a serious risk that liberalisation efforts may not lead to competitive network industries markets, but instead to markets that remain dominated by incumbent operators or that are fraught with anti-competitive practices. As indicated above, this could in turn deprive consumers and undertakings from the benefits, in terms of lower prices, better quality of service, and greater innovation that could be brought by liberalisation. More generally, the whole economy will suffer as network industries provide essential services for a large number of undertakings.

\section{Rules of Competition in the Association Agreements}

In this Part, we analyse the competition rules that are found in the association agreements concluded between the EC and the Euromed countries. We explore the reasons that have led to the adoption of such rules, as well as the content of such rules. (A). We also analyse the effectiveness, which, as we will see, is limited (B).

A. The insertion of competition rules in the Agreements concluded with the Euromed Countries

The insertion of competition rules in the agreements concluded between the EC and the Euromed countries is a recent phenomenon. It was initiated, on the one hand, with the launching of the accession process with the "eligible" candidates of the Euro- 
Mediterranean area (Cyprus, Malta and Turkey) and, on the other hand, with the opening of negotiations on a new generation of agreements (the "Euromed Agreements") with the other countries engaged in the Barcelona Process. Three main reasons explain this evolution.

A first reason is related to the impact of the discussions engaged in the WTO framework, as well as in other multilateral forums. For the past ten years, competition issues have been increasingly discussed at the international level. The exportation, by the EC, of its competition rules in regional trade agreements could help achieve a strategic result. The creation of a web of countries sharing the same competition law principles as the EC could give the latter a stronger negotiation position in the future WTO discussions over competition rules (Holmes 2002). A second reason lies in the accession process and the association agreements previously concluded with the CEECs. These agreements (the "Europe Agreements") already provided for competition rules similar to those of the EC Treaty. The replication of such rules in the Euromed Agreements shows a form of spill over effect of the Europe Agreements. It may also be explained by the willingness of the EC institutions to achieve a certain degree of standardization of the competition provisions of their external association agreements (Idot 2002). Finally, this evolution takes place within a process of increasing economic integration between the EC and the Euromed countries. The first generation agreements have efficiently dismantled most tariff and non-tariff barriers and have allowed increased market-access to foreign operators. Market access could, however, still be impeded by anticompetitive behaviours from private operators (Fox 1997\&1999). In order to eliminate potential obstacles to trade generated by anticompetitive practices, competition rules were enacted so as to complement the classic trade provisions.

The competition rules contained in the association agreements are similar to the rules which can be found in the EC Treaty. These provisions declare incompatible all (i) restrictive agreements between undertakings, (ii) abuses of a dominant position by one or more undertakings, and, for some countries only, (iii) State aids that distort, restrict or prevent competition. These provisions are only applicable in situations where trade between the EC and the partner countries is hampered. The agreements entrust the Council of Association with the duty to adopt implementation measures of these provisions. What these measures should be is not very clear, as no examples of such measures are available (no agreements have so far been implemented).

B. The Limited Effectiveness of the Competition Rules of the Association Agreements

The effectiveness of the competition provisions of the association agreements is very limited. This can be explained by two reasons. First, the implementation mechanisms instituted by the agreements are not efficient (1). Second, the degree of protection granted to individuals in the absence of implementation is poor (2).

\section{The Limited Efficiency of the Implementation Mechanisms}

Two elements play as limits to the implementation mechanism of the competition provisions. First, the time limits provided by the agreements for the adoption of implementation measures are not binding. This generates considerable delays in the 
implementation of the competition law provisions, thereby depriving them of any real effect in the short and middle term. As indicated above, none of the Association Agreements have so far benefited from implementation measures in the field of competition.

Second, the existence of a safeguard mechanism tends to limit the effectiveness of the competition provisions of the Agreements. The parties are left free to mitigate their conventional obligations with respect to competition rules and to exclude such rules to the benefit of their national laws. The hypothesis envisaged in the agreements is that of a practice that is incompatible with the competition provisions. If either Party considers (i) that the rules which are deemed to apply to it are not adequate, or (ii) that in the absence of such rules, its national interests or the interest of national undertakings are affected, it is entitled to unilaterally adopt a measure of coercion. In such instances, the Parties must seek an agreement within the Committee of Association. This organ is granted the power to adopt consultative opinions for such matters. The inherent limit to this procedure is that the Committee has a mere advisory function and the parties are not bound by its opinions (Hoekman 1998). This provision is thus likely to alter the cooperation mechanisms as regards competition law. Any Party which considers that its interests are being frustrated in any way, may feel free to take any appropriate measures at their discretion such as, for example, in the field of State aids, countervailing duties, etc. Since the definition of the interests and the appropriateness of a measure are left to the Parties to determine, it opens the way for a recalcitrant application of the agreements by a Party.

\section{The Degree of Protection enjoyed by Individuals}

As seen above, none of the existing Euromed Agreements have so far been completed by measures of implementation. It is generally considered that, in the absence of such measures, the competition rules of the agreements are not applicable. It is, however, subject to question whether alternative mechanisms could be used to offer a certain degree of protection to individuals that are victims of anti-competitive behaviour. Two approaches can be explored.

A first approach is to determine whether the competition provisions included in the association agreements could legally enjoy a "direct effect". In short, this concept consists in the possibility for individuals to invoke these provisions before national courts. The existence of a direct effect can legitimately be raised in the context of the Euromed Agreements. Indeed, those agreements replicate the competition rules of the EC Treaty, which enjoy direct effect within the EC legal order. Similarly worded norms contained in an international agreement could therefore be considered directly effective, even in the absence of implementation measures.

Two elements seem, however, to exclude this possibility. First, as suggested by several authors, no rule comparable to Protocol 35 of the EEE Agreement explicitly provides that the competition rules shall be "directly applicable" (Bourgeois 1993). Second, as seen above, since the implementation measures make the competition rules applicable, it must be logically presumed that until such measures are adopted, the provisions of the agreements are not effective. The degree of protection enjoyed by individuals on the basis of the association agreements is therefore extremely limited, at least until the agreement is implemented. 
A second approach is to explore whether in the absence of implementation measures and of direct effect, individuals could directly rely on the provisions of the EC Treaty to have anti-competitive practices carried out in the EC or in Euromed countries sanctioned. The relevant criterion here is to determine whether the practices in question have an impact within the EC (see the Woodpulp case). This mechanism, however, protects only individuals located within the EC. By contrast, the economic agents of the associated countries might have to rely on national rules of competition in order to be protected. As will be seen below, the effectiveness of such rules is, at least in some States, rather limited. For this reason, there is an asymmetric protection of individuals between the EC and the partner countries, irrespective of the existence of conventional competition rules.

\section{Domestic Competition Regimes in the Euromed Countries}

In the preceding Part, we have seen that the competition rules contained in the association agreements have only a limited scope as they are designed to prevent anticompetitive practices affecting trade between the EC and the Euromed countries (and thus offer no protection to practices that have only a local effect). Moreover, in absence of implementation measures, we have seen that their practical effect is limited. In this Part, we examine whether independently of the obligations imposed in the association agreements, Euromed countries have adopted domestic competition law regimes.

Among the partner countries, a distinction should be made between five categories of countries. The first category consists of the three countries engaged in the accession process (Cyprus, Malta and Turkey) which are accordingly submitted to three main obligations in the field of competition policy (Monti 2001). These countries must (i) show that the necessary legal framework for both antitrust and State aid has been created, (ii) make sure that an efficient administrative capacity be in place to apply the competition rules and (iii), show a concrete State aid and antitrust enforcement record. These countries have thus enacted EC-compatible competition regimes or are currently engaged in such a process. The second category is composed of Israel, which has had a very modern set of competition rules since 1988. The Israeli legislation ensures a high level of protection to economic operators and is built on a model that is conceptually more similar to the US Sherman Act and the former UK competition regime. The third category includes the Maghreb countries (Algeria, Morocco and Tunisia), which have adopted national legislations similar to the French Ordinance of 1 December 1986. A fourth group of States is composed of countries that have just adopted or are in the process of adopting domestic competition legislation. This is the case of Jordan, Egypt and Lebanon. Finally, a last group is composed of the countries that have not yet adopted domestic competition laws and that do not seem to be interested in such matters.

We will successively review the content (A) and the implementation (B) of the competition regimes established by the three first categories of countries. It is indeed impossible to provide an assessment of the Jordanian, Lebanese and Egyptian laws as they have either not been adopted or not yet been implemented. 


\section{A. Content of the Domestic Competition Laws}

As far as the first category of countries is concerned, the candidate countries have made significant achievements in the field of domestic competition law. Pursuant to the duty to implement the Acquis Communautaire in the field of competition policy, these countries have transposed the EC primary and secondary competition legislation (regulations, directives, notices, etc.) at the domestic level. In addition, these countries have set up credible institutions. In this respect, the "stick and carrot" method pursuant to which the candidate countries will not enter the EC unless they show satisfactory results has proven efficient in the field of competition policy.

Nevertheless, the candidate countries face a variety of recurrent problems, including the fact that: (i) the Commission considers their enforcement policies are too weak (Cyprus and Malta), (ii) some sectors are often exempted from the application of State aid rules (Malta and Turkey); and public undertakings remain out of the scope of the antitrust domestic legislation (Turkey). Because of these problems, the Commission has recently taken the view that, to the exception of Cyprus, the accession negotiations over the competition Chapter could not yet be closed.

The second category, i.e., Israel has adopted a somewhat different domestic competition regime. While the Israeli Law on the Restrictive Trade Practices sets up a modern competition regime, the terminology used largely differs from that used by EC competition law. In this respect, the Israeli Law is closer to the former UK antitrust regime and the US antitrust law.

At the substantive level, the Israeli Law apprehends three types of practices. First, it prohibits all restrictive agreements. These agreements have to be notified to the "Court for Trade Restrictions" and to the Director of the authority. An exemption can be granted if the agreement enters the list of legal exceptions relating to "public good", or if the agreement does not have a significant effect on competition according to a decision of the Director of the authority. Second, the Israeli Law imposes a series of obligations as regards monopolies. The monopoly and the monopolist are placed under a quasi-monitoring regime. Thus, every 6 months, the Director must provide a list of all the monopolists to a parliamentary committee. In addition, monopolists shall not behave so as "to reduce" competition or "harm the public". An indicative list provides instances of abuse. Moreover, even when no case of abuse has been identified, the Court can regulate the monopoly if, as the result of its existence, the public is being harmed. The Court can thus deliver instructions to monopolists and, under exceptional circumstances, can order measures of de-monopolization, upon request of the Director. Finally, mergers between companies are submitted to preliminary authorisation. The Director of the authority can prohibit those operations that significantly harm competition or the "public". The latter can also deliver unconditional decisions, conditional decisions (including corrective measures), or opposition decisions.

The institutional provisions of the Israeli Law establish a hierarchical, independent and specialised organization. A "Court for Trade Restrictions" is entrusted with a wide range of powers to address anticompetitive practices (injunctions, provisional measures, etc). Its decisions can be challenged before the Supreme Court of Israel. A competition authority known as the "Trade Restrictions Authority" is also established 
by the Israeli Law and enjoys important powers. It is placed under the responsibility of a Director named by the Government.

The third category of countries (The Maghreb Countries) has largely inspired from the French competition regime. Algeria, Morocco and Tunisia have all adopted domestic competition laws that are modelled on the French Ordinance of $1^{\text {st }}$ December 1986.

At the substantive level, the competition laws of the Maghreb countries prohibit, on the one hand, all agreements, concerted practices and collusions that may have for object or effect to prevent or restrict free competition and, on the other hand, all abuses of a dominant position. All three prohibitions are complemented by an exemption mechanism according to which the two-abovementioned kinds of practices can be authorized when they ensure a certain technical or economic progress. The assessment of such progress is made in accordance with the principle of the "bilan économique" known in French competition law, as well as in EC competition law. Lastly, the mergers between undertakings are submitted to an authorization procedure. The assessment criterion of such operations is the creation or strengthening of a dominant position as understood under EC competition law. In all three countries, public authorities are entitled to control the prices of certain products. The implementation of such price controls is strictly limited as it is only authorized either when competition does not exist for structural reasons or in the event of significant economic disturbances (e.g. natural disasters or exceptional circumstances).

At the institutional level, the three Maghreb countries instituted a competition authority known as the "Competition Council" that has presumably been modelled on the authority instituted by the French Ordinance of 1986. In Algeria and Tunisia, these authorities are given a wide range of functions (i.e. carrying out studies, drafting regulatory proposals, and engaging in cooperation with other authorities) and enjoy decision, injunction and sanction powers. By contrast in Morocco the Competition Council does not enjoy a real decision-making power and the Prime Minister is the only authority qualified to rule on anticompetitive practices. In addition, the filing of complaints before the Competition Council is not satisfactory. Indeed, only the administration is qualified to seize the Council, after having decided on the opportunity to further support the complaint of an operator. The control of competition is thus primarily political and doubts can be raised regarding its neutrality.

It thus appears that the competition laws adopted in the three categories of countries examined above are of a reasonable quality. They prevent the type of anti-competitive conducts, which are generally found in modern competition legislation, and contain institutional provisions establishing competition law authorities.

As one of the key elements of a competition law regime lies in its implementation and enforcement the next Part analyses the way in which these laws have been implemented and enforced in practice.

\section{B. Implementation and Enforcement of the Domestic Competition Laws}

Evaluating the quality of implementation and enforcement in the Euromed countries is no easy task, as the decisions adopted by their competition authorities are generally 
not published, and many of these authorities are not bound to produce annual reports accessible to the public. The analysis that follows is thus based on the data we managed to gather from Commission reports and from the specialised literature.

In the candidate countries, the enforcement of domestic competition laws seems satisfactory. This may be explained by the stringent obligations resulting from the accession procedure. Indeed, the candidate countries must not only transpose the EC framework, but also prove a credible enforcement record in the field of antitrust and State aids (Monti 2001). Thus, the candidate countries have, for the past five years, made increasing progress in the field of enforcement of their domestic competition regimes. In this respect, the latest evaluation reports of the European Commission witness encouraging results. It is for instance reported that, during the year 2000, the Turkish Competition Authority adopted 262 decisions relating to anticompetitive agreements and abuses of a dominant position, 101 decisions relating to mergers and acquisitions, and 23 decisions granting exemptions or negative clearances (Mumcu and Zengibonuz 2002). Beyond these figures what is important is that the Turkish Competition Authority has decided some high profile cases, including cases in the area of network industries (OECD 2001).

The situation may similarly be considered satisfactory for Israel. The 2001 annual report of the Israel competition authority shows a relatively high degree of enforcement activity. It is for instance reported that the authority reviewed 160 notifications of mergers operations. In addition, the competent courts have also ruled on an important number of dealing with anti-competitive conducts, including cartels and abuses of a dominant position.

By contrast, competition law enforcement in the Maghreb countries is inadequate. While two years after the adoption of the competition law, the Moroccan competition authority is not yet operative, the Tunisian and Algerian authorities that have been in place for several years have had a limited output. For instance, it has been reported that during the period of six years that followed its creation (from mid-1991 to mid1997) the Tunisian Competition Council issued only three decisions, two of which were rejecting complaints and one condemning an abuse of a dominant position (El Hédi Lahouel 2000). During this period, it also delivered opinions on five occasions on projects of legislation addressed to it for consultation by the Minister of Commerce. The Algerian competition authority has been in existence since 1995. Since its creation, it has issued 6 decisions, all concerning alleged abuses of dominant position. These decisions led to injunctions and, in certain instances, to the condemnation to pecuniary penalties.

The low level of enforcement achieved in these countries could be explained by the deterrent effect of the domestic competition laws produced on economic operators. We believe, however, that this is not the case here. A competition law regime may only have a deterrent effect on operators provided certain conditions are met, such as the presence of severe sanctions in the competition laws, the adoption of several high profile decisions showing that the competition are serious about their enforcement mission, etc. As far as the Maghreb countries are concerned, none of these conditions are met.

It is more reasonable to consider that other factors explain the low enforcement 
performance of these authorities. As has been shown by Kovacic, the reasons explaining the weakness of enforcement of competition policy in emerging economies are multiple: insufficient powers of the controlling authorities, insufficient resources, limited substantive expertise, frail academic infrastructure, weak professional associations and consumers groups, insufficiently trained judiciary, opposition to the economic reforms and weak access to competition-related business data (Kovacic 1997). These elements may easily be transposed to the Maghreb countries, where institutional capacity in the field of competition is limited.

These elements should into account when providing technical assistance to the partner countries. Without taking these elements into account, it is probable that the enforcement of competition rules will remain insufficient.

\section{Conclusion}

Competition policy is an increasingly important issue in the Euromed countries. As we have seen, the association agreements concluded between the EC and these countries contain competition law provisions. In addition, several Euromed countries have adopted domestic competition laws. While the adoption of competition rules at the regional and domestic levels should be welcomed, our analysis suggests that these provisions have very limited practical impact. As far as the Euromed Agreements are concerned, this is largely due to the fact that the associated countries have so far failed to adopt implementation measures, thereby depriving the competition provisions of the association agreements of any effect. As far as the domestic level is concerned, the lack of effectiveness of the competition rules can be explained by the weaknesses of the enforcing authorities. These authorities are generally inexperienced and suffer from insufficient expertise in competition matters. The economic operators of such countries are also not aware of the benefits that they could gain from invoking efficiently such provisions. The absence of an effective competition policy in the Euromed countries may result in harmful consequences for both consumers and undertakings that remain insufficiently protected against anti-competitive practices. Furthermore, as explained above, the absence of effective competition policies may also result in particular difficulties in the network industries sector. Indeed, the adoption and implementation of a competition policy is an essential component of the market opening that has been carried out in several Euromed countries. If such competition rules were to remain absent or ineffective, the potential benefits that could result from liberalisation, in terms of lower prices, as well as increased quality and innovation, would largely be neutralised.

\section{References}

Anderson, Robert D. and Holmes, Peter, "Competition Policy and the Future of the Multilateral Trading System”, 5 (2002) Journal of International Economic Law, 531

Andress Isabel, "Postal Sector Reforms in the Mediterranean Region", PPMI News, Issue $\mathrm{n}^{\circ}$ 3, March 2002, available at http://wbln0018.worldbank.org/eurvp/web.nsf/Pages/Issue+n.+3+March+2002/\$File/ PPMI+NEWSLETTER-+ISSUE+03+-+MARCH+2002.PDF 
Araujo, Jose Tavares de, Jr. and Tineo, Luis, "Harmonization of Competition Policies Among Mercosur Countries", 24 (1998) Brooklyn Journal of International Law, 441

Bellamy and Child, European Community Law of Competition, $5^{\text {th }}$ Ed., P.M. Roth Ed., Sweet \& Maxwell, 2001

Bourgeois, Jacques H.J., p.130, in "Competition Policy and Commercial Policy" p.113 in Marc Maresceau Ed., (1993), The European Community's Commercial Policy after 1992: The Legal Dimension, Martinus Nijhoff Publishers

Brennan, Timothy J., "Regulated Firms in Unregulated Markets: Understanding the Divesture in US v. AT\&T”, (1987) 32, Antitrust Bulletin, 741

Cunningham, Richard and LaRocca, Anthony, "Harmonization of Competition Policies in a Regional Economic Integration", 27 (1996) Law and Policy of International Business, 879

El Hédi Lahouel, Mohamed, "Competition Laws in MENA: An Assessment of the Status Quo and the Relevance of a WTO Agreement", Paper Prepared for the Third Mediterranean Development Forum, Cairo, 5-8 March 2000.

Ehlermann, Claus-Dieter, "The Contribution of EC Competition Rules to the Single Market”, Vol. I, (1992) Common Market Law Review, 29.

European Commission, 2002 Regular Report on the Progress towards Accession, $\operatorname{COM}(2002) \quad 700 \quad$ final. Available at http://www.europa.eu.int/comm/enlargement/report2002/index.htm

Fox, Eleanor M., "Competition Law and the New Millennium Round", 2 (1999) Journal of International Economic Law, 665

Fox, Eleanor M., "Toward World Antitrust and Market Access", 91 (1997) American Journal of International Law, 1

Gal, Michal S., "Size Does Matter: The Effects of Market Size on Optimal Competition Policy", 74 (2001) Southern California Law Review 1437, 1451

Gellhorn, Ernest and Kovacic, William E., Antitrust Law and Economics in a Nutshell, (1994), $4^{\text {th }}$ Ed., West Publishing, St. Paul, Minn., 42

Geradin, Damien, "The Opening of State Monopolies to Competition: Main Issues of the Liberalization Process" in, D. Geradin Ed., The Liberalization of State Monopolies in the European Union and Beyond, Kluwer Law International, (1999), p. 181.

Goldstein, Andrea, "Institutional Endowment and Regulatory Reform in Telecoms: A Five-Country Comparison in the MEDA Region", OECD Development Center, The Integration of Developing Countries into the World Trading System, Table 5.

Guzman, Andrew, "Is International Antitrust Possible?", 73 (1998) New York 
University Law Review 1501.

Hoekman, Bernard, "Competition Policy and Preferential Trade Agreements", 7 (1998), available at http://www.worldbank.org/wbi/publications/wbi37131.pdf

Holmes, Peter, "Trade and Competition in the New WTO Round" in Chris Milner and Robert Read Ed., "Trade Liberalization, Competition and the WTO" (2002) Edward Elgar in association with the International Economics Study Group, 147

Idot, Laurence, "Mondialisation, Liberté et Régulation de la Concurrence - Le Contrôle des Concentrations" 2-3 (2002) Revue Internationale de Droit Economique Numéro Spécial Mondialisation et Droit Economique, 175

Jenny, Frédéric, "Globalization, Competition and Trade Policy", in International and Comparative Competition Laws and Policies, Yang-Ching Chao, Gee San, Changfa Lo, Jiming Ho Eds., (2001), Kluwer Law International, 45

Kerf, Michel and Geradin, Damien, "Controlling Market Power in Telecommunications: Antitrust vs. Sector-specific Regulation", 14 (1999) Berkeley Technology Law Journal, pp. 919-1020

Kerf, Michel and Geradin, Damien, "Post-Liberalization Challenges in Telecommunications, Balancing Antitrust and Sector-specific Regulation - Tentative Lessons from the Experiences of the United States, New-Zealand, Chile and Australia”, 23 (2000) World Competition, 27

Kovacic, William E., "Getting Started: Creating New Competition Policy Institutions in Transition Economies”, 23 (1997), Brooklyn Journal of International Law, 403

Larouche, Pierre, Competition Law and Regulation in European Telecommunications, Hart Publishing, Oxford, 2000

Levenstein, Margaret and Suslow, Valerie, "Private International Cartels and Their Effect on Developing Countries", background paper for the World Bank's Development Report 2001, 9 January 2001

Monti, Mario, "Enforcement of Competition Policy - Case for the Accession Negotiations and for Developing a Real Competition Culture" $7^{\text {th }}$ Annual Competition Conference between Candidate Countries and the European Commission, Ljubljana, Slovenia 17-19 June 2001

Monti, Mario, "EU Competition Policy", Fordham Annual Conference on International Antitrust Law \& Policy, New York, 31 October 2002

Müller Jentsch, Daniel, "Recent Trends in Electricity Sector Reforms in the EuroMediterranean Area", PPMI News, Issue ${ }^{\circ}{ }^{1}$, January 2002, available at http://wbln0018.worldbank.org/eurvp/web.nsf/Pages/Issue+n.+1+January+2002/\$File /PPMI+NEWSLETTER+-+ISSUE+01+-+JAN+2002.PDF

Mumcu, Ayse, and Zengibonuz, Unal, “Competition Policy in Turkey”, paper 
prepared for the ERF $8^{\text {th }}$ Annual Meeting, Cairo, 15-17 January 2002

Newbery, David M., Privatization, Restructuring and Regulation of Network Utilities, (2000) Cambridge, Mass., and London, MIT Press

OECD Annual Report on Competition Law and Policy, (2001-2002). Available at http://www.oecd.org/EN/document/0,EN-document-768-nodirectorate-no-11-38098$\underline{768,00 \cdot h t m l}$

Porter, Michael, The Competitive Advantage of Nations, Free Press, 1990, 117

Tarullo, Daniel K., "Norms and Institutions in Global Competition Policy", 94 (2000) American Journal of International Law 478

Wood, Diane P., “The Impossible Dream: Real International Antitrust”, (1992)

University of Chicago Legal Forum, 277 


\section{Annex I}

\section{Summary Table of the Domestic Competition Laws of the Euromed Countries}

\begin{tabular}{|c|c|c|c|c|c|c|c|}
\hline & $\begin{array}{c}\text { Material scope of } \\
\text { application } \\
\text { equivalent to EC } \\
\text { competition law } \\
\text { (i) }\end{array}$ & $\begin{array}{l}\text { State aid control } \\
\text { mechanism }\end{array}$ & $\begin{array}{l}\text { Applicability } \\
\text { to all } \\
\text { economic } \\
\text { activities }(i i)\end{array}$ & $\begin{array}{c}\text { Objectives of the } \\
\text { competition law } \\
\text { regime broader than } \\
\text { maintaining a } \\
\text { competitive market } \\
\text { structure (iii) }\end{array}$ & $\begin{array}{c}\text { Independent } \\
\text { institutions / } \\
\text { authorities (iv) }\end{array}$ & $\begin{array}{c}\text { Effective } \\
\text { institutions } \\
\text { authorities } \\
(v)\end{array}$ & \begin{tabular}{|c|} 
Alignment on \\
EC \\
competition \\
law $(v i)$
\end{tabular} \\
\hline Cyprus & Yes & Yes & Yes & $(\ldots)$ & Yes & Yes & Yes \\
\hline Malta & Yes & Yes & No & $(\ldots)$ & Yes & No & No \\
\hline Turkey & Yes & No & No & (...) & Yes & No & No \\
\hline Algeria & Yes & $(\ldots)$ & Yes & Yes & Yes & No & No \\
\hline Morocco & Yes & $(\ldots)$ & Yes & Yes & No & No & No \\
\hline Tunisia & Yes & $(\ldots)$ & Yes & Yes & Yes & No & No \\
\hline Israel & Yes & $(\ldots)$ & No & No & Yes & Yes & No \\
\hline
\end{tabular}

(i) The question covered here is whether the domestic competition law covers all the prohibitions contained in EC competition law (Article 81, Article 82, EC Merger Regulation).

(ii) The question covered here is whether some economic activities or some undertakings are explicitly exempted from the application of the competition law. Public undertakings will not be considered as exempted when entrusted with a service of general economic interest as provided by Article 86(2) of the EC Treaty.

(iii) The question covered here is whether the competition laws that have been analysed above protect interests others (consumer information, price transparency, etc.) than the protection of a competitive market structure.

(iv) The question covered here is whether the competition authority enjoys a real decision-making power or is submitted to a political control when taking a decision.

(v) The elements taken into account are the following: number of decisions adopted, type of decisions adopted, average period for review, number of actions brought before the authority, etc.

(vi) It is here made reference to the three criteria formulated by the European Competition Commissioner, Mario Monti.

(...) In the absence of sufficiently detailed data, the corresponding entries have been left unanswered. 